\title{
Pysicochemical Characterization of Nano Calcium phosphate from Milkfish's (Chanos - Chanos Forks) Bone Flour in Duration of Autoclaving and Boiling Time Different Muhammad Fitri ${ }^{1,2}$, Mursalim $^{3}$, Amran Laga ${ }^{3}$, and Zainal ${ }^{3}$ \\ ${ }^{*}$ Post-Graduate Student, Hasanuddin University, Makassar, South Sulawesi, Indonesia ${ }^{2}$ Department of Fishery Product Processing Technology, Pangkep State Polytechnic of Agricultural, Pangkep, South Sulawesi, Indonesia \\ ${ }^{3}$ Department of Agricultural Engineering and Food Technology, Hasanuddin University Makassar, South Sulawesi, Indonesia
}

\begin{abstract}
According to the Food and Agriculture Organization in 2018, milkfish 1,188,000 tons (2016) or 2\% of the world's total fish (2016) (The State of World Fisheries and Agriculture, 2018). South Sulawesi milkfish production is the highest in Indonesia. Milkfish production in 2016, to 127,434.1 tons (Anonymous, 2018). Milkfish is a fishery commodity in Pangkep Regency, in 2016 has increased by 28,759 tons (Anonymous, 2018), an increase in fish consumption it will also increase of milkfish bone waste. The use of milkfish bone waste as a source of calcium is an alternative provide a calcium-rich food source. The purpose of this research is to study the physicochemical of milkfish bone calcium phosphate with in duration of autoclaving and boiling time differently. The treatment are in duration of autoclaving (A) $A_{1}=1,5, A_{2}=2$, and $A_{3}=2,5$ hours, and boiling time (B) $B_{1}=30, B_{2}=60$ and $B_{3}=90$ minute. The design used is complete randomized design with two factors, consist of three level. Each treatment was repeated three times. The data analysis by variance analysis using SPSS V. 21 software. The parameters measured are yield, water, ash, protein, fat, calcium and phosphorus. Milkfish bone in this study contained the highest calcium $41.87 \%$ and phosphorus $25.86 \%$ obtained from a combination of 2.5 hours autoclaving and boiling length 90 minutes. Yield 36.59\%, moisture 5.22\%, ash 77.87\%, protein $25.13 \%$, and fat content $4.01 \%$.
\end{abstract}

Keywords : Milkfish, Nano Calcium Phosphate, Autoclaving, Boiling

\section{INTRODUCTION}

South Sulawesi Province has a high potential for marine and fisheries and has a diversity of fish species. This makes South Sulawesi a miniature of marine and fisheries in Indonesia. South Sulawesi seaweed and milkfish production is the highest in Indonesia. As for the achievements of milkfish production in 2016, which amounted to $127,434.1$ tons, equivalent to 18.9 percent of national production (Anonymous, 2018).
Milkfish is a fishery commodity in Pangkep Regency, South Sulawesi Convention in 2016 has increased by 28,759 tons, this shows that milkfish production has increased sharply from year to year with a sharp increase of 13.9 percent (Anonymous, 2018). Milkfish is a fishery commodity of Pangkep regency in South Sulawesi Province. Increasing the value of milkfish production increased from year to year with a fairly sharp value. With the increase of milkfish consumption, there is also an increase in bone waste 
volume of milkfish who not much benefit. Utilization of milkfish bone waste as a source of calcium is an alternative in order to provide calcium rich food source as well as reduce the negative impact of environmental pollution (Hafiludin, 2015). Calcium derived from animals such as fish bone waste so far has not been widely used for human needs. Though fish bones contain tri calcium phosphate (tricalcium phosphate, dicalcium phosphate, and hydroxylapaptite) which is ideal for the human body (Basmal J, et all ,2000). Calcium requirement is 500 $\mathrm{mg}$ day ${ }^{-1}$ for ages $1-9$ years,700 $\mathrm{mg} \mathrm{day}^{-1}$ for ages 10 15 years, $600 \mathrm{mg} \mathrm{day}^{-1}$ for ages $16-19$ years and 500 $800 \mathrm{mg}$ day $^{-1}$ for adults (age 20 to over 60 years) (Almatsier, 2004).

Bone is one form of waste generated from the fish processing industry that has the highest content of calcium in the fish body. From a food and nutritional standpoint, fish bones are rich calcium that needed human, because the main elements of fish bones are calcium, phosphorus and carbonate. Thus, fish bone waste has great potential to be utilized as a raw material of fish bone rich in calcium. Fish bones contain a lot of mineral salts such as calcium phosphate and creatine phosphate which has the potential to increase the nutrients of food products (Maulida, N. 2005).

One of the artificial bone coating materials that can be used is hydroxyapatite (HAp). HAp has the molecular formula $\mathrm{Ca}_{10}\left(\mathrm{PO}_{4}\right)_{6}(\mathrm{OH})_{2}$. This material has been recognized as a substitute for bone and teeth, because it has a biological similarity for human hard bone tissue (Vijayalaksani \& Rajeswari 2006; Xiangian et al. 2009.). According to Balamurugan et al. (2002), HAp is able to protect metal implants from corrosion when implanted in the body. HAp has excellent biocompatibility properties because it is resistant to corrosion, resistant to the toxic effects produced by corrosion, resistant to changes during use of materials in the body's environment and does not cause a rejection reaction from body tissues. In addition, HAp has bioactive properties because it can stimulate new bone growth around implants (Pane, 2004).

The aim of this research is to study the quality of nano calcium phosphate from bone flour of milkfish (Chanos - Chanos Forks), By using in duration of autoclaving and boiling frequency different.

\section{METHODS AND MATERIAL}

\section{A. Research Site}

It was carried out at the Chemical Laboratory of State Agricultural Polytechnic of Pangkep and Science Centre of Mathematics and Natural Science Faculty of Hasanuddin University, Chemistry Departement of Science Centre of Mathematics of Islamic University of Makassar.

\section{B. Materials and Tools}

\section{Material}

In this study the materials used were bone of milkfish, $\mathrm{MgSO}_{4}, \mathrm{HCl} 0.01 \mathrm{~N}, \mathrm{H}_{2} \mathrm{BO}_{3}, \mathrm{Na}_{2} \mathrm{~S}_{2} \mathrm{O}_{3}, \mathrm{HgO}$, Neutral Alcohol, PP Indicators, distilled water and some Zink, etc.

\section{Tools}

The tools used in the processing procedure are stoves, knives, blenders, pans, basins, grinders, digital scales, packaging. While the tools for chemical analysis are Erlenmeyer, Kjeldhal flask, test tube, condenser, oven, boiling rock, distillation flask, exicator, buret and others as needed in research

\section{Sample Preparation}

This research will be conducted this year. analyze the quality of milkfish bone flour nano calcium 
phosphate by using in duration autocalving differently by treatment $A_{1}=1,5$ hours, $A_{2}=2$ hours and $\mathrm{A}_{3}=2,5$ hours and to analyze the physicochemical of milkfish bone nano calcium phosphate by using boiling time frequency differently by treatment. $\mathrm{B}_{1}=30$ minute, $\mathrm{B}_{2}=60$ minute and $\mathrm{B}_{3}=90$ minute with frequency interval 30 minute.

The research design used was complete randomized design, With two factors and every factor consist of three levels. Each treatment was repeated three times. The observation data analyzed by variance analysis using SPSS V. 21 software. If the results of the variance analysis show a significant or very significant effect, then the middle value tested by using Duncant's Significant Difference test. Parameters under observation is yield, water, ash, protein, fat, calcium and phosphorus.

The tests conducted to determine physicochemical the nano calcium phosphate quality, which are physicochemical characterization of each treatment. Chemical composition test including yield, water content with the oven method (AOAC, 925.092005 dalam Lekahena 2013), ash content (AOAC,941.12 2005), protein content by Kjeldahl micro method (AOAC,920.87.2005), fatcontent (AOAC 960.39.2005), Calcium content (AOAC 968.08.2005), phosphorus content (AOAC 948.09 2005)

\section{Processing Procedures}

Raw materials (milkfish bone powder), to produce raw materials of bones ready for extracted milkfish have gone through several stages of the process such as washing, boiling $\left(80{ }^{\circ} \mathrm{C}, 30\right.$ minute), Washing, Autoclaving $\left(121^{\circ} \mathrm{C}, 1 \mathrm{~atm}, 1,5\right.$ hours, 2 hours, and 2,5 hours), and reducing the size using a hammer mill $( \pm 5 \mathrm{~cm})$. The second stage is Boiling $\left(100{ }^{\circ} \mathrm{C}, 30\right.$ minute ( frequency first), 60 minute (frequency second), 90 minute (frequency third), Washing, drying (water content $<8$ percentage) and milling which aims to soften the fish bones so as to facilitate the process of flouring (Nabil, M. 2005).

\section{Extraction with in duration 1, 5 hour autoclaving with boiling time frequency 30,60 , and 90 minutes with frequency interval 30 minutes.}

Treatment $A$ is 100 percentage rough powdered bone of milkfish was extracted with in duration 1,5 hour with boiling frequency with $\mathrm{A}_{1}=30$ minute, $\mathrm{A}_{2}=60$ minute and $A_{3}=90$ minute at $100^{\circ} \mathrm{C}$ for frequency interval 30 minutes. This extraction process repeated 3 times. The extraction results are then cooled, filtered, neutralized to neutral $\mathrm{pH}$ and dried by oven at $50^{\circ} \mathrm{C}$ to a water content of $<8$ percentage.

\section{Extraction with 2 hours autoclaving with boiling time frequency 30,60 , and 90 minutes with frequency interval 30 minutes.}

Treatment B is 100 percentage rough powdered of milkfish bone is hydrolyzed with 2 hours autoclaving with boiling time frequency 30, 60, and 90 minute with frequency interval 30 minute.Then extracted at $100^{\circ} \mathrm{C}$. The extraction process was repeated 3 times and the extraction result was then cooled, filtered and neutralized using distilled water up to a neutral $\mathrm{pH}$ sample, then dried in oven at $50^{\circ} \mathrm{C}$ until it reaches the water content of $<8$ percentage. extracted Milkfish bone powder that extracted then made into flour using a disc mill then sieved using 100 mesh size. Sterilization process carried out at $121^{\circ} \mathrm{C}$ for 15 minutes to maintain the quality and extend the shelf life of the resulting bone powder

\section{Data Analysis}

The research design used was complete randomized design, With two factors. Each treatment was repeated three times. The observation data analyzed 
by variance analysis using SPSS V. 21 software. If the results of the variance analysis show a significant or very significant effect, then the middle value tested by using Honestly Significant Difference test. Parameters under observation is yield, water, ash, protein, fat, calcium and phosphorus.

\section{RESULTS AND DISCUSSION}

1. Results of Analysis of Milkfish (Chanos chanos Forks) Bone Flour Yield (Rendement) in Duration of Autoclaving and Boiling Time Different

The average yield of the length autoclaving treatment and boiling time samples ranged from 40.80 to $36.59 \%$ with an average of $38.71+1.70 \%$. The longer autoclaving and boiling time will give a low yield can be seen in Figure 1, this is caused by the longer autoclaving and boiling time will eliminate all organic components found in the bones along with autoclaving time and boiling time to produce a purer mineral form.

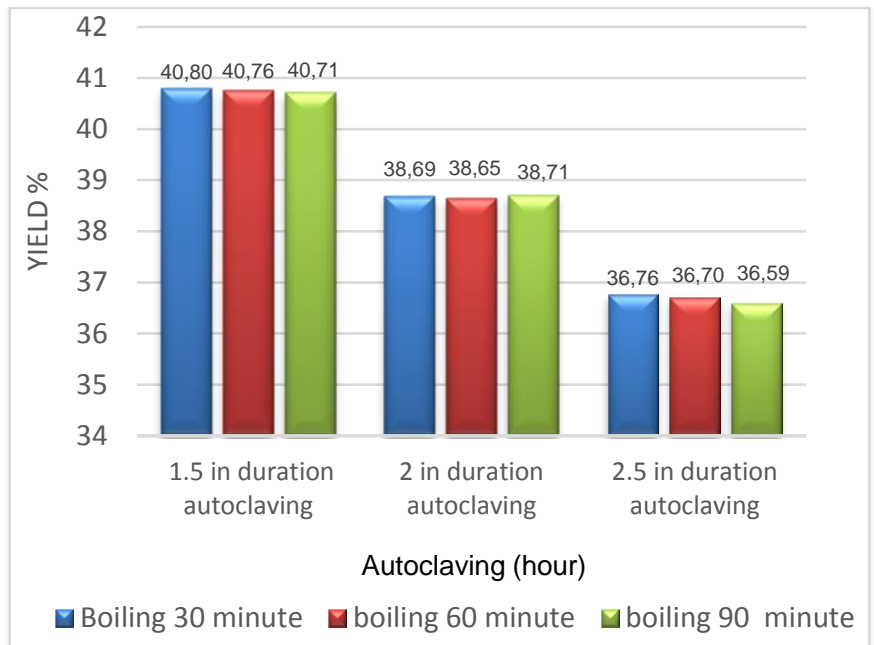

Figure 1. The Relationship between the Effect of Autoclaving Time and Boiling Time on the Yield Content of Milkfish (Chanos-chanos Forks)Bone Flour

Based on the treatment of autoclaving time difference significantly ( $p<0.05)$, while boiling time and interaction did not significantly affect ( $p>0.05$ ) The value of yield in this study was higher than that of Trilaksani et al. (2006) range of $13.28-28.85 \%$, the results of the study of Lekahena et al. (2014) a range of $3.49-7.39 \%$. The yield value in this study is lower than that of Hanura et al. (2017) a range of 57.73$61.05 \%$.

2. Results of Analysis of Milkfish (Chanos chanos Forks) Bone Flour Water Content in Duration of Autoclaving and Boiling Time Different

The value of water content in the duration autoclaving treatment with boiling time in this study (Figure 2) ranged from 7.76-5.22\%

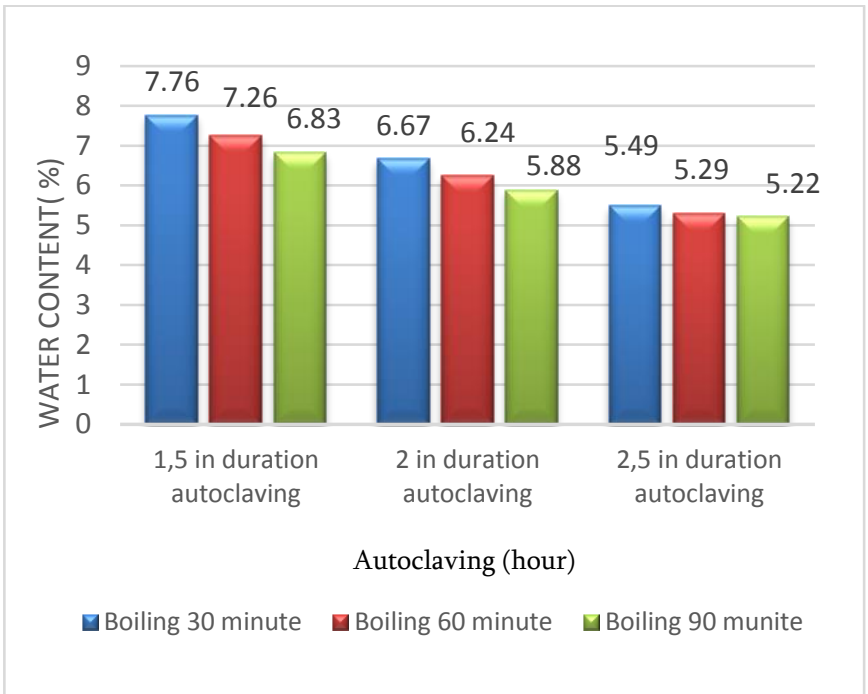

Figure 2. The Relationship between the Effect of Autoclaving Time and Boiling Time on the Water Content of Milkfish (Chanos-chanos Forks) Bone Flour

is almost the same as the results of Murtiningrum's research (1997) ranged from 7.20 to $4.54 \%$, Trilaksani et al (2006) ranged from 8.30 to $5.60 \%$, Lekahena (2014) ranged from 8.76-4.29\%, whereas it is lower than the research conducted by Nurmala et al. (2006) was $12.57 \%$, higher than snapper bone meal moisture content in the study of Dongaran et al. (2007) was 
$2.20 \%$, the water content of tilapia bone meal in the Hemung study (2013) was $2.46 \%$, the water content of tuna hydroxyapatite flour in Hanura et al. (2017) which is $0.15 \%$. The difference in water content is influenced by the type of fish bones, the drying method, and the extraction method. According to Reo (2011) states that the drying time, drying temperature and surface area of the material can affect the water content of a material, Daud (2019) states that the method of drying and surface area of the material, as well as the container where the dried material affects the water content. This value is still in the range of standards set by Indonesia's National Standard (SNI 01-3158-1992) for bone meal moisture content (maximum 8\%), but higher than the bone meal moisture content of the International seafood of Alaska (ISA) production which is $3.4 \%$ and Mulia (2004) of 3.3\%.

Based on the difference of autoclaving time, boiling time and interaction between autoclaving time and boiling time significantly $(\mathrm{p}<0.05$ ) on the calcium phosphate moisture content of milkfish bone meal

\section{Results of Analysis of Milkfish Chanos chanos} Forks) Bone Flour (Ash Content in Duration of Autoclaving and Boiling Time Different

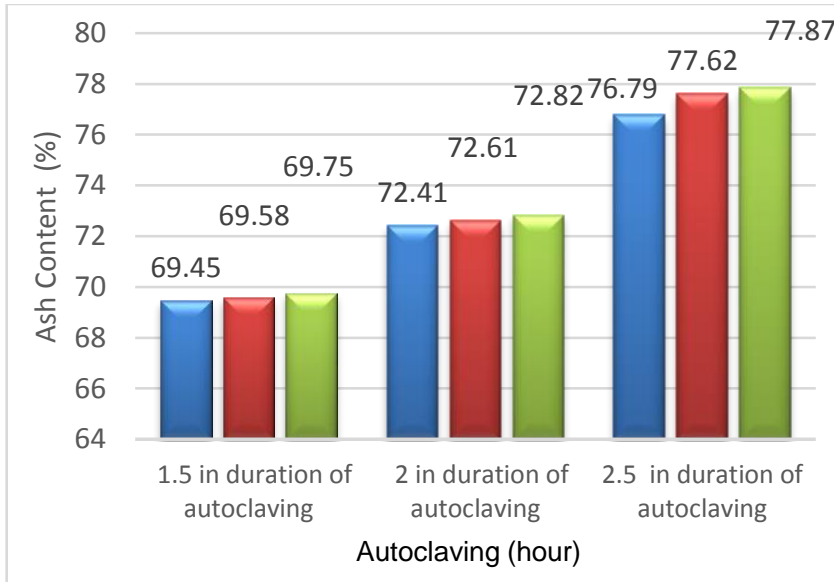

$\boldsymbol{\square}$ boiling 30 minute $\boldsymbol{\square}$ boiling 60 minute $\boldsymbol{\square}$ boiling 90 minute
Figure 3. The Relationship between the Effect of Autoclaving Time and Boiling Time on the Ash Content of Milkfish (Chanos-chanos Forks) Bone Flour

Ash content of a food product shows the residue of organic matter which is after organic matter in the food is destroyed. Ash content analysis aims to find out how much mineral content is contained in hydroxylapatite, tricalcium, dicalcium milkfish bone flour. Bone contains living cells and intracellular matrix in the form of mineral salts. The mineral salt consists of calcium phosphate, as much as $80 \%$ and the rest is calcium carbonate and magnesium phosphate (Frandson 1992). Ash content of an ingredient is the amount or mineral content of a food ingredient. Minerals contained in an ingredient include two kinds of salt, namely organic salt, for example: acetic acid salt, and inorganic salt, such as chloride salt or $\mathrm{NaCl}$ (Winarno, 2000). Ash content reflected the amount of mineral content in a material, the higher the ash content, the greater the mineral content, and vice versa. According to Lesbani et al. (2011) high ash content indicated high mineral content in a material.

The ash content of milkfish bone nano calcium phosphate in this research higher than the bone powder standard based on ISA standards (International Seafood of Alaska) 33.1 percentage the same the results of research conducted (Mulia. 2004) 63,5 percentage, the same (Elfauziah R.2003) 79,14 percentage.

These many are influence content of mineral, content ash influenced time duration autoclaving and frequency boiling the significant influence of ash content, protein and fat bone flour. . bone before processing content cell alive and intracellular matrics in form the salt mineral. Ash content who high in the bone flour caused by main component manage bone is 
mineral and process it's making had occur hydrolysis protein who almost total that produced protein the lowest.

4. Results of Analysis of Milkfish (Chanos chanos Forks) Bone Flour Protein Content in Duration of Autoclaving and Boiling Time Different

Based on Figure 4. The protein content in the autoclaving duration and boiling time shows different values based on the autoclaving treatment period and boiling time and its interaction between autoclaving time and boiling time significantly influencing $\mathrm{p}$ $<0.05$ The protein content of autoclaving duration treatment with boiling time

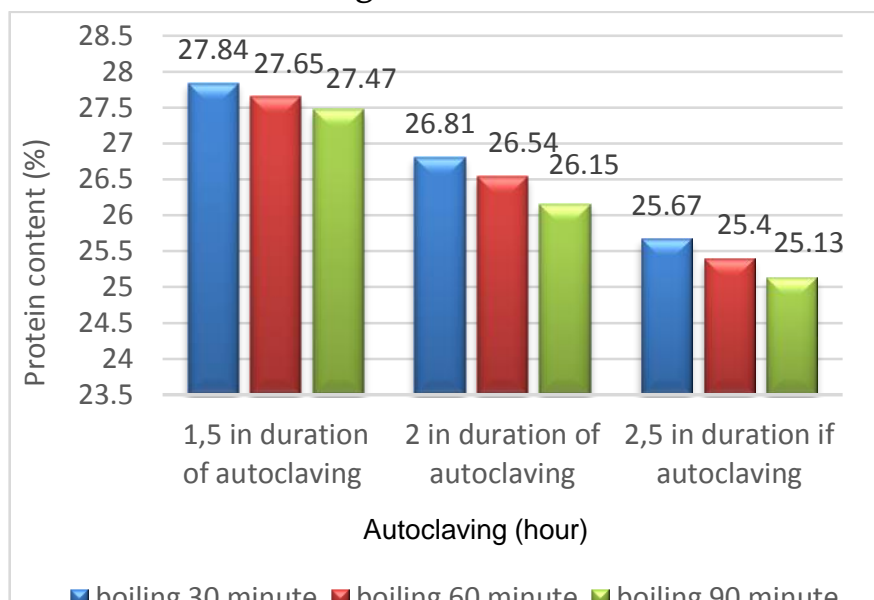

Figure 4 Relationship between the Effect in duration of Autoclaving and Boiling Time on Protein Content of Milkfish (Chanos-chanos Forks) Bone Flour

Protein levels obtained were lower with protein levels obtained by ISA (Rans, 2002), which was 34.20, higher than the results of Elfauziah's (2003), Mulia's (2004) research, which were 16,90 , and 11.08 (\%), respectively. The low protein content in this milkfish bone flour can be beneficial and detrimental when viewed from the aspect of nutrition and absorption of calcium in the intestine, because calcium can be absorbed well when in the form of calcium chloride salt, calcium gluconate, calcium carbonate and calcium phosphate. Calcium phosphate is a mineral source that has very good biological value (Kaup et al., 1991). Besides that protein is also very instrumental in the absorption of calcium into the intestinal mucosa because calcium transportation through intestinal cells can occur through diffusion using the services of calcium-binding proteins that deliver to the cytoplasm.

Based on the Duncan test in the subset of autoclaving duration treatment was significantly different between the three treatments and the lowest was autoclaving length of 2.5 hours which is $25.40 \%$ which means the longer the autoclaving the lower the protein content produced.

Based on the Duncan test in the subset of boiling time treatment is significantly different between the three treatments and the lowest is boiling time 90 minutes which is $26.25 \%$ which means the longer the boiling the lower the protein content produced.

5. Results of Analysis of Milkfish (Chanos-chanos Forks) Bone Flour Fat Content in the Autoclaving and Boiling Time Different

The results of the analysis of the variance carried out on the fat content showed significant differences between the autoclaving duration, boiling time and the interaction between autoclaving duration, boiling time significantly affected $(\mathrm{p}<0.05)$. The milk fat content of milk fish is in the range of $7.87-4.01 \%$, with an average of $6.20 \%$ almost the same as the fat content of tilapia flour done by Hemung (2013) which is $5.82 \%$, the fat content of tuna flour (Trilaksani et al. 2006) $4.13 \%$ and higher fat content of catfish flour (Rich et al. 2008) which is 2.09\%. Tilapia flour fat content (Lekahena, 2013) ranged from 0.87-2.85, tuna bone fat fat content (Hanura et al. 2017) is $0.05 \%$, tilapia bone flour fat content 
(Anggran et al. 2016) is $1.21 \%$. The results of milkfish flour fat test results can be seen in Figure 5, The Indonesian National Standard (SNI 01-3158-1992) sets the fat content for fish flour to quality I of $3 \%$ bb and quality II of $6 \% \mathrm{bb}$. Referring to these standards, the milkfish bone flour fat content from the treatment of autoclaving treatment with boiling time is included in quality II. Low fat content makes quality relatively more stable and not easily damaged. High fat content can cause flour to have fish taste and cause oxidative rancidity due to fat oxidation (Almatsier, 2004).

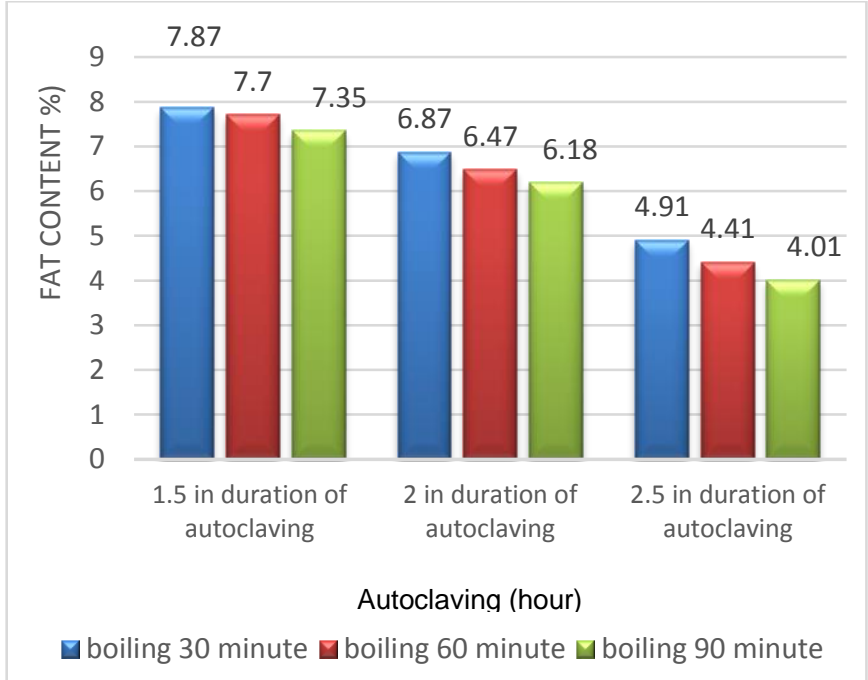

Figure 5 Relationship between the Effect in duration of Autoclaving and Boiling Time on Fat Contents of Milkfish (Chanos-chanos Forks)Bone Flour

Fat is found in the bone matrix, especially the main bone of fish, which consists of many joints of bone, even the fat cannot be released easily, because it is a complex bond, and difficult to remove only by immersing the bone in an alkaline solution (Hemung, 2013). The level of fat in the bones is closely related to the body fat of each species, and usually large and mature fish contain high fat, fish fatty acids are unsaturated fatty acids. Fatty acids in fish bone flour in some species were found to contain nearly $80 \%$ unsaturated fatty acids (Toppe et al. 2007). Still high levels of fat in the first treatment because only a short pressing and boiling

\section{Results of Analysis of Milkfish (Chanos-chanos} Forks) Bone Flour Calcium Content of with Autoclaving Length and Boiling Time different

One ingredient that contains high minerals is fish bone meal which has high calcium and phosphorus content. According to Orias (2008), besides having a high mineral content of calcium content in fish, especially in fish bones forming complexes with phosphorus in the form of apatite or tricalcium phosphate. This form causes fish bone meal to be easily absorbed by the body, ranging from $60-70 \%$. Calcium levels produced in the first treatment in this first study can be seen in Figure 6,. The level of calcium produced ranged from 38.07 - 41, 87\% with an average of $39.88 \%$. This value is above the standard range of calcium levels determined by SNI for fish bone flour, which is $30 \%$ (quality I) and $20 \%$ (quality II).

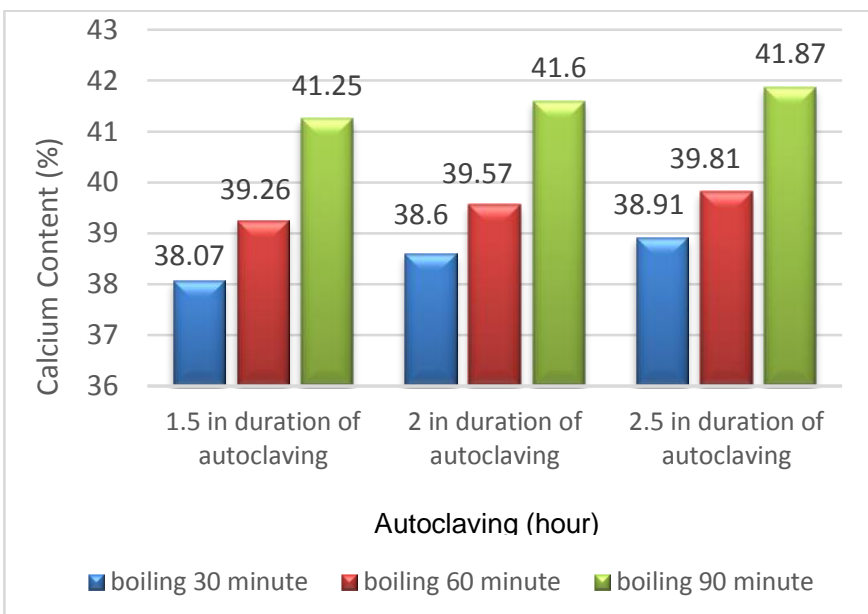

Figure 6. Relationship between Effect of Autoclaving Time Treatment and Boiling Time on of Calcium Content Milkfish (Chanos-chanos Forks Bone Flour

The results of the analysis of variance showed that the autoclaving duration and boiling frequency as well as 
the interaction between the two significantly affected ( $p<0.05)$ on calcium levels. this shows that the mineral element is relatively unstable with autoclaving and boiling time, the more the frequency of boiling is done it shows an increase in calcium levels. Calcium levels in this study were higher when compared to calcium levels of tilapia bone meal conducted by Lakehena et al (2014) which only ranged from 18.70 to $21.47 \%$, calcium levels produced by balide fish meal (Kusmungrum et al., 2016) ranged from 29.29-31.31\%, almost the same level of calcium produced in tuna bone meal (Trilaksani et al., 2006) ranged from $23.72-39.24 \%$, calcium levels produced in yellow scaly tuna bone flour (Nemati et al. 2017) ranged from $24.56-38.16 \%$.

7. Levels of Milkfish (Chanos-chanos Forks) Bone Flour Phosphorus () in the Autoclaving Time and Boiling time different Treatments

Phosphorus is the second most macromineral after calcium in the body, $85 \%$ of phosphorus is in bones. Calcium and phosphorus form calcium phosphate or calcium hydroxyapatite crystals $\left[3 \mathrm{Ca}_{3}\left(\mathrm{PO}_{4}\right)_{2} \mathrm{Ca}(\mathrm{OH})_{2}\right]$ as the main constituent of bones (Sabri, 2011). Phosphorus levels of all samples as shown in Figure 7,



Autoclaving (hour)

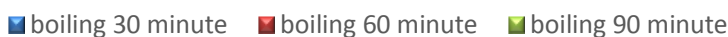

Figure 7. Relationship between Effect of Autoclaving Time Treatment and Boiling Time on of PhosphorusContent Milkfish (Chanoschanos Forks Bone Flour

The results of analysis of various levels of phosphorus in the autoclaving duration and boiling time significantly affected $(\mathrm{p}<0.05)$, while the interaction between autoclaving duration and boiling time did not significantly affect ( $\mathrm{p}>0.05)$ ). Phosphorus levels from the results of this study were higher than those of Trilaksani et al. (2006) ranged from 11.34-14.25\%, from the results of the study of yellow scaly tuna bones (Nemati et al., 2017) ranged from 14.58$23.31 \%$, from the results of studies of sardine fish bones (Logesh et al. , 2012) ranged from 7.21-17.2\%, from the results of nano hydroxyapatite studies of tuna fish bones (Hanura et al., 2017) which is $9.02 \%$, the results of nano calcium phosphate research from tilapia bones (Lekahena et al., 2014) ranged from 8.86-12.05\%, the results of nano calcium phosphate research from tilapia (Anggraen et al., 2016) are $8.65 \%$. Phosphorus content of this study is higher than the results of studies of various types of fish from the western coast of Norway (Toppe et al., 2006) ranged from 0.081 to $0.11 \%$, the results of bone studies of yellowfin tuna (Zobda et al., 2016) namely $0.36 \%$,

\section{CONCLUSIONS}

The results of the analysis obtained a combination of 2.5 hours autoclaving duration with boiling time of 3 times (90 minutes) which is the best of the other treatments. Milkfish bone flour in this study contained the highest calcium $41.87 \%$ and phosphorus $25.86 \%$ obtained from a combination of 2.5 hours autoclaving treatment and 3 times boiling (90 minutes). Yield 36.59\%, moisture content 5.22\%, ash content $77.87 \%$, protein $25.13 \%$, fat $4.01 \%$, 


\section{REFERENCES}

[1]. Almatsier. 2004. Basic Principle of Nutrient Science. PT Gramedia Pustaka Utama, Jakarta

[2]. Anggraeni N., Yudhomenggolo, Sastro D., dan Putut H.R., 2016 . Utilization Nanocalcium of "Nila" Oreochromis niloticus) Fish Bone on Analog hulled rice from many kinds Sweet Potato (Ipomoea batatas L.).Journal Techonoly Application ;5(4)

[3]. Association Official Analitical Chemistry. 2000. Official Methods of Analysis. Arlington, New York

[4]. Apriyantono A., Fardiaz D., Puspitasari NL., Sedarnawati, Budiyanto S., 1989. Inter-University Center for Food and Nutrition. Bogor Agricultural Institute

[5]. Basmal J, Yeni Y, Murdinah, Suherman M, Gunawan B. 2000. Technical Report. Product Processing Research and Economics and Social. Jakarta

[6]. Cucikodana Y. 2013. The Boiling Temperature Different Effect and $\mathrm{NaOH}$ Concentration of Quality Snakefish (Channastriata) Bone Powder (Mini Thesis) Inderalaya : Agriculture Faculty of Sriwijaya University

[7]. Elfauziah R.2003. Separation Calcium from Bone and Head of "Patin" Fish (Pangasius sp.).(Mini Thesis) Fishery and Ocean Science. IPB.Bogor. National Standardization for Bone Powder. SNI 01-31581992. Jakarta: National Standardization Council

[8]. Ferazumma H., Sri A. M., Amalia and Laily, A., 2011. Substutition of dumbo catfish (Clarias gariepinus) flour to increase calcium crackers content. Journal of Nutrition and Food 6 (1): 18-27

[9]. Hafiludin 2015. Nutrient Contain of Milkfish Who who Come From The Different Habitat . Ocean Journal Volume 8 No 1 April 2015. ISSN 1907-9931

[10]. International Seafood of Alaska ISA]. 2002. Analysis of Fish Powders.www.kodiak.com

[11]. Lekahena V., D.N. Faridah., R. Syarief dan R. Peranginangin. 2014.Characteristics of Nano Calcium Physical Chemistry Result Extraction "Nila "Fish Bone with Using Alkaline and acid Solution. Journal Technology and Food Industry 25 (1), 57-64

[12]. Ocean and Fishery Ministery (2011) Ocean and Fishery in Number. Ocean and Fishery Minister.
Jakarta Ocean and Fishery Minister , 2011. Increasing of Shrimp Production

[13]. Maulida, N. 2005. Utilization Powder Bone of Madidihang Fish (Thunnus albacores) is Supplement in Making Crackers (Mini thesis) Bogor. Ocean and Fishery Faculty IPB

[14]. Mohanraj VJ., Chen Y., 2006. Nanoparticle-a review Trop J Pharma Res $5: 561-573$

[15]. Mulia. 2004. Potential Study of "Patin (Pangasiussp) Fish Bone Waste is Course Calcium Alternative in Dry Mie Product (Mini Thesis) Bogor. Fishery and Ocean Science IPB.

[16]. Nabil, M. 2005. Utilization waste of "Tuna" Fish (Thunnus sp.) Bone is Calcium Source with Protein Hydrolysis Method (Mini Thesis) Bogor. Faculty Fishery and Ocean Science IPB

[17]. Sokartono.S.T., 1985. Sensory Assesment . Bhatara Karya Aksara Publisher. Jakarta

[18]. Wardani,Dini, Liviawaty dan Junianto, 2012. Fortifikasi tepung tulang ikan tuna sebagai sumber kalsium terhadap donat .Jurnal Perikanan dan kelautan 3(4):41-50

[19]. Winarno, F. G., F. Srikandi dan D. Fardiaz. 1988. Food Technology Introduction. PT Gramedia Pustaka Utama. Jakarta

[20]. Winarno, F. G., F. Srikandi dan D. Fardiaz.. 2002 Food and Nutrient Chemistry. Jakarta. PT Gramedia Pustaka Utama

\section{Cite this article as :}

Muhammad Fitri, Mursalim, Amran Laga, Zainal, "Pysicochemical Characterization of Nano Calcium phosphate from Milkfish's (Chanos - Chanos Forks) Bone Flour in Duration of Autoclaving and Boiling Time Different", International Journal of Scientific Research in Science and Technology (IJSRST), Online ISSN : 2395-602X, Print ISSN : 2395-6011, Volume 6 Issue 6, pp. 71-79, November-December 2019. Available at doi :

https://doi.org/10.32628/IJSRST196617

Journal URL : http://ijsrst.com/IJSRST196617 